\title{
Why We Don't Know Much About the Archaic Period in Northeast Texas
}

Ross C. Fields

Prewitt and Associates, Inc.

Follow this and additional works at: https://scholarworks.sfasu.edu/ita

Part of the American Material Culture Commons, Archaeological Anthropology Commons, Environmental Studies Commons, Other American Studies Commons, Other Arts and Humanities Commons, Other History of Art, Architecture, and Archaeology Commons, and the United States History Commons

Tell us how this article helped you.

This Article is brought to you for free and open access by the Center for Regional Heritage Research at SFA ScholarWorks. It has been accepted for inclusion in Index of Texas Archaeology: Open Access Gray Literature from the Lone Star State by an authorized editor of SFA ScholarWorks. For more information, please contact cdsscholarworks@sfasu.edu. 


\section{Why We Don't Know Much About the Archaic Period in Northeast Texas}

Creative Commons License

(c) (i) (8)

This work is licensed under a Creative Commons Attribution-NonCommercial 4.0 International License 


\title{
WHY WE DON'T KNOW MUCH ABOUT THE ARCHAIC PERIOD IN NORTHEAST TEXAS
}

\author{
Ross C. Fields
}

While there have been a few studies in recent years that have offered some interesting ideas about the lifeways of the Native Americans that occupied Northeast Texas during Archaic times (e.g., Fields and Tomka 1993; Johnson 1989; Story 1990), most of what we know (or think we know) about the subject is based on limited data, and much of that data really is not of very good quality. For example, we think that Archaic peoples were nomadic hunter-gatherers who roamed the landscape, staying in one spot only for a few weeks or less until they had collected all the hickory nuts or hunted all the deer they could find there. In general, this notion is probably correct, but it does not present a very complete picture of their lifeways, and when you get down to it, it is not really based on much hard archaeological evidence.

Why are our data on the Archaic period so poor? First and foremost, the majority of the Archaic materials that we have are from sites where the sediments have not built up much over the past few thousand years and where later Woodland and Caddoan peoples also camped. While I can think of a few sites in such non-aggrading (or very slowly aggrading) settings that do not have later materials mixed in (e.g., the John Pearce site in Caddo Parish, Louisiana [Webb et al. 1971]), this is not very common. Much more frequently, we see a handful of Archaic dart points coming off sites where the primary component is later. In some cases, as at the Jake Martin site in Upshur County (Davis and Davis 1960), Woodland and Caddoan components are not present, but the range of dart points recovered clearly indicates that multiple Archaic components are represented, and these kinds of sites are problematic as well.

In these situations, it is impossible to separate out the artifacts that go with particular Archaic components, except for the dart points and perhaps a few other distinctive tool types. What this means is that we seldom are able to isolate tool kits (i.e., the range of tools) that Archaic peoples used in their daily lives. This makes it difficult to look at the range of activities they performed at their campsites, among other things.

For example, I have found that it is very useful to be able to isolate not only the tools but also the debitage left from manufacture of the tools, because this helps us distinguish between local and non-local materials and tells us a great deal about how the non-local lithics arrived at the sites. In some situations, as at Cooper Lake, tools made of non-local materials are not frequent and debitage is even less frequent. In this case, it is clear that the people who lived at Cooper Lake only occasionally obtained lithic tools through trade (i.e., they were not involved in well-developed and extensive trade networks that involved lithics) and that the tools they received were already in finished forms.

In contrast, non-local lithics are much more common at the Jewett Mine in Archaic contexts, and at many sites debitage of non-local materials is more frequent than tools. It is clear that these people were involved in the importation of lithics from Central Texas (or maybe even direct procurement), partial reduction into large tool blanks, and then exportation of the blanks, presumably into East Texas proper. Without the ability to isolate both tools and debitage into assemblages, we would not have been able to gain a very clear understanding of how these systems worked.

To this point, the discussion has dealt entirely with shortcomings introduced by the fact that most of the investigated sites with Archaic components are in poor geomorphic contex ts for 
the isolation of components. There are, of course, other serious and pervasive limitations. Several of the most obvious relate simply to the age of Archaic sites. That is, organic materials are poorly preserved in these older sites, and they tend not to contain much in the way of macrobotanical or faunal remains. Lacking materials for dating, it is hard to develop precise (or even general) chronologies, and without direct information on the kinds of plants and animals that Archaic peoples used, it is hard to be very concrete when talking about their subsistence practices.

Despite these kinds of problems, I think that gaining a better understanding of Archaic lifeways is an attainable goal, and the remainder of this paper presents a brief case study that I think illustrates this point. It is based on one of the better Archaic sites that I have worked on in Northeast Texas, the Finley Fan site at Cooper Lake (Gadus et al. 1992). Finley Fan was found during a 1989 survey by Southern Methodist University in which they identified landforms that might contain buried sites and then did extensive trenching. Their trenches resulted in the discovery of two burned rock features, one of which yielded charcoal dated to 4800 B.P., associated with a modest artifact scatter. All of the cultural materials were buried, and there was no evidence of the site on the surface.

When we returned in 1990, we dug more trenches and some test pits to figure out where we should devote our efforts, and then we dug two small blocks of $25 \mathrm{~m}^{2}$ each. One was targeted at a shallowly buried component at $20-80 \mathrm{~cm}$ bs, and the other sampled a deeper component at $150-210 \mathrm{~cm}$ bs. We ended up excavating 10 features, all of them burned rock concentrations, and recovering about 3,900 lithic artifacts, most of which were pieces of debitage. We did not recover any animal bones and very little macrobotanical remains, although we did find enough charcoal to obtain five more radiocarbon dates. In addition, we submitted six sediment samples for dating of soil humates to help us understand the chronology of the site.

When we coupled the dating results with the geomorphic evidence, we found out that the site was in an alluvial fan that started building up about 12,000 years ago and stopped accumulating about 1,600 years ago. In that time, over $6 \mathrm{~m}$ (20 feet) of sediments were deposited there, with the build-up happening rapidly at first and then slowing down over time. What that meant was that the site had an excellent potential to contain archaeological deposits that could be separated into relatively discrete components, perhaps even representing single occupations, and that it could contribute the kind of information that we do not get from Archaic sites that are mixed with later materials. Unfortunately, Finley Fan did not deliver fully on this promise.

The reason for this was that the site occupied only the upper third of the alluvial fan deposits, and since build-up of the fan slowed down over time, the materials left by individual occupations were not readily separable. This was not a big problem with the more deeply buried component because it contained a small number of artifacts (including only one typeable dart point, a Yantis) and may have represented as few as two occupations. The upper component presented more of a problem. It contained far more artifacts, and the 16 typeable dart points were so variable typologically (Yarbrough, Dawson, Gary, Kent, Morrill, Trinity, Wesley, and Yantis) that it seems certain that a fair number of individual occupations are represented, even though only two could be identified based on the stratigraphy. The possibility of numerous episodes of use is strengthened further by the radiocarbon evidence, which suggests that the deposits containing the upper component accumulated over a span of as much as 1,500 years.

The upshot of all this is that the Finley Fan site, while definitely in a better geomorphic context for isolating generalized components (or periods of use) than most excavated sites with Archaic components, was not a site where very discrete components (i.e., single 
occupations) could be isolated. Further, it had other shortcomings. Charcoal was not abundant, and while we got enough radiocarbon dates to propose a chronology, we were not able to get dates on some important features. With more dates, I think the chronology would have been refined considerably. We also did not recover macrobotanical or faunal remains to tell us what kinds of plant and animal foods the people ate. Finally, our understanding of the site is limited by the small size of our excavations. While the $50 \mathrm{~m}^{2}$ that we dug may seem like a fair amount, it is just a drop in the bucket compared to the site as a whole. Our excavations exposed concentrations of archaeological materials that we think probably represent hearth-centered activity areas, but because of the size of the excavations I cannot estimate how many such activity areas may have been used at any one time.

Having said all this, I now want to emphasize just how good this site was. This can be done best by listing some of the things we learned:

1. Yantis points may be relatively diagnostic of the late part of the Middle Archaic period and the early part of the Late Archaic;

2. a wide variety of dart point styles were used in the Late Archaic, including some (e.g., Yarbrough and Morrill) that traditionally have been thought to date earlier, and others (e.g., Gary and Kent) that remained popular after the Archaic;

3. all of the dart points are of types with easterly distributions in Texas, suggesting sufficient intra-regional interaction to lead to some degree of uniformity in dart point styles;

4. the artifacts were concentrated within $2 \mathrm{~m}$ of the hearths and the overall artifact concentrations generally were $6 \mathrm{~m}$ less in diameter, suggesting that the site was used on a relatively short-term basis by small groups of people;

5. the site lacked a midden, contained only one kind of feature (i.e., burned rock concentrations interpreted as hearths), yielded relatively numerous expedient stone tools, and had lower artifact densities than most of the later sites at Cooper Lake, supporting the idea that the site saw short-term use for a relatively limited range of activities, although it probably was residential in nature (i.e., a campsite used by a whole social group); and

6. stone tools made of non-local materials were not common, but they were more frequent than in later sites, and this suggests that Archaic peoples ranged over larger areas, including the Red River valley to the north, than later peoples (i.e., they were not as settled).

All in all, I think we learned a fair amount from the Finley Fan site, particularly since we could compare it to later sites in the same area. We could have learned even more, though, if the site had been different in some important ways. The things that would have made it a better Archaic site (and that we need to be looking for in other Archaic sites in Northeast Texas) include better stratification and vertical separation of components, better preservation of macrobotanical and faunal remains, and more extensive excavations. 


\section{References Cited}

Davis, W. A. and E. M. Davis

1960 The Jake Martin Site: An Archaic Site in the Ferrell's Bridge Reservoir Area, Northeastern Texas. Archaeology Series No. 3. Department of Anthropology, The University of Texas at Austin.

Fields, R. C. and S. A. Tomka

1993 Hunter-Gatherer Mobility in Northeast Texas, 10,000-200 B.C. In Archeology in the Eastern Planning Region, Texas: A Planning Document, edited by N. A. Kenmotsu and T. K. Perttula, pp. 69-95. Cultural Resource Management Report 3. Department of Antiquities Protection, Texas Historical Commission, Austin.

Gadus, E. F., R. C. Fields, C. B. Bousman, S. A. Tomka, and M. A. Howard

1992 Excavations at the Finley Fan Site (41HP159), Cooper Lake Project, Hopkins County, Texas. Reports of Investigations No. 78. Prewitt and Associates, Inc., Austin.

Johnson, L., Jr.

1989 Great Plains Interlopers in the Eastern Woodlands during Late Paleoindian Times. Report 36. Office of the State Archeologist, Texas Historical Commission, Austin.

Story, D. A.

1990 Cultural History of the Native Americans. In The Archeology and Bioarcheology of the Gulf Coastal Plain, by D. A. Story, J. A. Guy, B. A. Burnett, M. D. Freeman, J. C. Rose, D. G. Steele, B. W. Olive, and K. J. Reinhard, pp. 163-366. 2 Vols. Research Series No. 38. Arkansas Archeological Survey, Fayetteville.

Webb, C. H., J. L. Shiner, and E. W. Roberts

1971 The John Pearce Site (16CD56): A San Patrice Site in Caddo Parish, Louisiana. Bulletin of the Texas Archeological Society 42:1-49. 